\title{
How water level management affects cladoceran assemblages in lakes lateral to a reservoir
}

\author{
José Roberto Debastiani-Júnior ${ }^{\mathrm{A}, \mathrm{B}}$ and Marcos Gomes Nogueira ${ }^{\mathrm{A}}$ \\ A Departamento de Zoologia, Instituto de Biociências de Botucatu - UNESP, Distrito de Rubião Jr, \\ s/n, CEP 18618-970, Botucatu, SP, Brazil. \\ ${ }^{B}$ Corresponding author. Email: debastianijunior@gmail.com
}

\begin{abstract}
This study analysed the effects of induced water level depletion for macrophyte control in a tropical reservoir on the cladoceran fauna of two differentially connected lateral lakes. One lake, Pedra Branca, is located in the right margin and has a narrow connection to the main river-reservoir channel as well as a higher proportion of submerged macrophytes. On the opposite margin is Lake Guaritá, which is shallower and has a wider connection. Samples were collected over 16 consecutive months, including periods before, during and after depletion. Both lakes showed closely related trends in depth, $\mathrm{pH}, \mathrm{DO}$, conductivity, chlorophyll, temperature, suspended matter, phosphorus, nitrogen, silicate and ammonium variation, although a wider amplitude in variation was observed in Pedra Branca. This lake also had higher cladoceran diversity and a predominance of Chydoridae, whereas Bosminidae prevailed in Guaritá. Depletion caused a reduction in richness and an increase of Bosminidae in both lakes, although this was more pronounced in Pedra Branca. The management moderately affected both lakes but continuous application of this procedure may lead to a shift in the system steady-state and a loss of diversity that could be difficult to reverse.
\end{abstract}

Additional keywords: Bosminidae, Chydoridae, connectivity, macrophyte control, reservoir management.

Received 29 July 2014, accepted 18 August 2015, published online 10 December 2015

\section{Introduction}

Most reservoirs directly affect the adjacent floodplains and associated wetlands, which are areas whose high biodiversity and ecological functional importance have been highlighted by many authors (Junk et al. 1989; Ward 1989; Ward et al. 1999; Zalocar de Domitrovic 2002; Poi de Neiff 2003; José de Paggi and Paggi 2008).

Despite the high flow control in adjacent water bodies, lakes marginal to a reservoir can exhibit a distinctive limnological variability (Pelicice et al. 2005; Ferrareze et al. 2014) and high habitat heterogeneity, both temporally and spatially, increasing the potential for colonisation by many species (Thomaz et al. 2008). Shallow lakes, such as those associated with rivers and reservoirs, are usually colonised by macrophytes. These plants provide habitat structure for the aquatic communities, including benthic and phytophilous invertebrates (Shimabukuro and Henry 2011), fish (mostly juveniles) (Ferrareze and Nogueira 2011) and zooplankton (Jeppesen et al. 1997).

Nevertheless, the excessive growth of macrophytes makes access to the open water of reservoirs difficult for fisheries and recreational activities and can also obstruct intake of water into turbines in hydropower dams. It has been demonstrated that lowering the water level is a possible tool for macrophyte control in reservoirs (Thomaz et al. 2006) but little is known about the effects on the associated fauna, for instance, on the Cladocera (Crustacea).
Cladocerans comprise more than 180 zooplanktonic, phytophilous and benthic species in the Neotropical region (Forró et al. 2008), are directly influenced by human interventions on aquatic ecosystems and play a prominent role in aquatic food webs, transporting energy from primary producers and detritus to higher trophic levels (Roche and Rocha 2005; Sarma et al. 2005).

This study analysed the effects of sudden lowering of the water level, carried out once per year for macrophyte control, on cladocerans of two lateral lakes connected to Salto Grande reservoir, a run-of-river reservoir (Nogueira et al. 2012). It compared the responses of the lake fauna in relation to their differential degrees of physical connection to the main channel. Connectivity in a broad sense is considered a major factor in the structuring of communities and maintenance of regional biodiversity in floodplain and wetland ecosystems (Junk et al. 1989; Scheffer and van Geest 2006).

With regard to how the operational drawdown affects the two lakes, we hypothesised that (1) the lake with wider connection, named Guaritá, would experience more rapid changes in the cladoceran fauna due to significantly higher water exchanges with the main channel; (2) the lake with narrower connection, Pedra Branca, would have higher microhabitat heterogeneity, community diversity and resistance but possibly greater variation in physical and chemical variables (magnification of internal lake metabolism), which could negatively affect the organisms under consideration. 


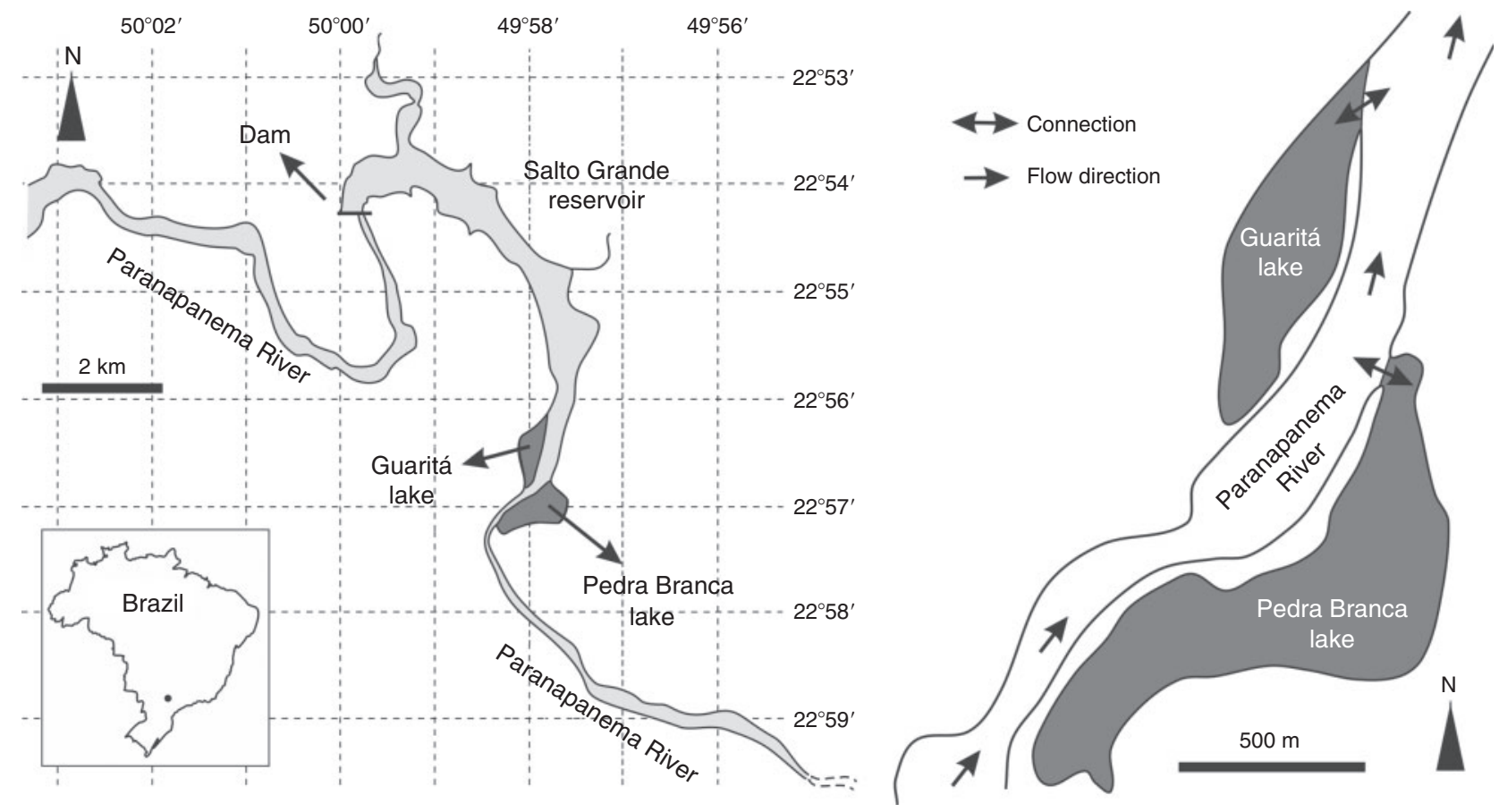

Fig. 1. Map of Salto Grande Reservoir highlighting the lakes Pedra Branca and Guaritá.

\section{Materials and methods}

\section{Study area}

The two studied lakes, Pedra Branca and Guaritá, are connected to the Salto Grande Reservoir, a run-of-river reservoir on the Paranapanema River on the border of São Paulo and Paraná States, Brazil (Fig. 1). Lake Pedra Branca $\left(22^{\circ} 56^{\prime} 28^{\prime \prime} \mathrm{S}\right.$, $49^{\circ} 58^{\prime} 02^{\prime \prime} \mathrm{W}$ ) is located on the right margin of the river and has a narrower connection to the reservoir than Lake Guaritá $\left(22^{\circ} 56^{\prime} 17^{\prime \prime} \mathrm{S}, 49^{\circ} 57^{\prime} 39^{\prime \prime} \mathrm{W}\right)$, on the left margin. Both lakes are shallow, especially Guaritá, with a maximum depth of $\sim 3 \mathrm{~m}$, and are densely colonised, especially Pedra Branca, by submerged aquatic macrophytes, mainly Egeria densa Planchon.

Operational lowering of the water level (drawdown) is conducted every year during the dry season (autumn-winter) to expose shore macrophytes to dehydration with the aim of decreasing plant biomass (Fig. $2 a$ ). The dead plants are partially removed by local residents and municipal authorities before restoration of the normal operational water level. The depth and volume of both lateral lakes are strongly reduced. At the lowest water level, Guaritá still remains connected to the reservoir through two small channels $\sim 5 \mathrm{~m}$ wide. Pedra Branca is totally disconnected.

\section{Data collection}

The field work conducted in this study encompassed the period before, during and after the operational procedure, from April 2005 to July 2006 (16 consecutive months).

In the limnetic (central) zone of each lateral lake, vertical profiles of water temperature, $\mathrm{pH}$, dissolved oxygen (DO) and electric conductivity were determined with a Horiba U22 water probe (Horiba Ltd, 2 Miyanohigashi, Kisshoi Minami-ku, Kyoto, Japan). Water transparency was measured with a Secchi disc (Labmatrix Importação e Comércio LTDA, Araras, SP, Brazil). Water samples were collected to determine chlorophyll-a (Strickland and Parsons 1960), total nitrogen (Mackereth et al. 1978) total phosphorus (Strickland and Parsons 1960) after physico-chemical digestion (Valderrama 1981), ammonia and silicate (Golterman et al. 1978) and suspended matter (SM) (gravimetric analysis). The depth of the lakes at the sampling sites was measured with Speedtech sonar (Depthmate model SM-5, Speedtech Instruments, Unionville, VA, USA). At the beginning, middle and end of the management procedure (Days 1, 7 and 15) and 1 month later (September 2005), for comparison, samplings were performed every $4 \mathrm{~h}$ (nycthemeral cycles), to identify the immediate effects of the drawdown event.

Simultaneously, we conducted monthly sampling of cladocerans in both lakes. For quantitative analysis, samples corresponding to a total volume of $150 \mathrm{~L}$ were collected with a bucket in the centre of each lake and filtered through a $55-\mu \mathrm{m}-\mathrm{mesh}$ zooplankton net. For qualitative analysis, we performed vertical net hauls. Both samples were fixed in $4 \%$ formalin. During the depletion period, samples were obtained during the day and night at the beginning, middle and end of the drawdown event (Days 1, 7 and 15). A minimum of 150 individuals were counted, or, in cases of low abundance, the whole sample was counted under a stereomicroscope. The cladoceran taxa were identified under a Carl Zeiss Standard 25 microscope following the relevant literature (e.g. Korovchinsky 1992; Smirnov 1996; Elmoor-Loureiro 1997; Orlova-Bienkowskaja 1998). The total abundance, richness and Shannon-Wiener diversity were calculated after the counting of samples. 

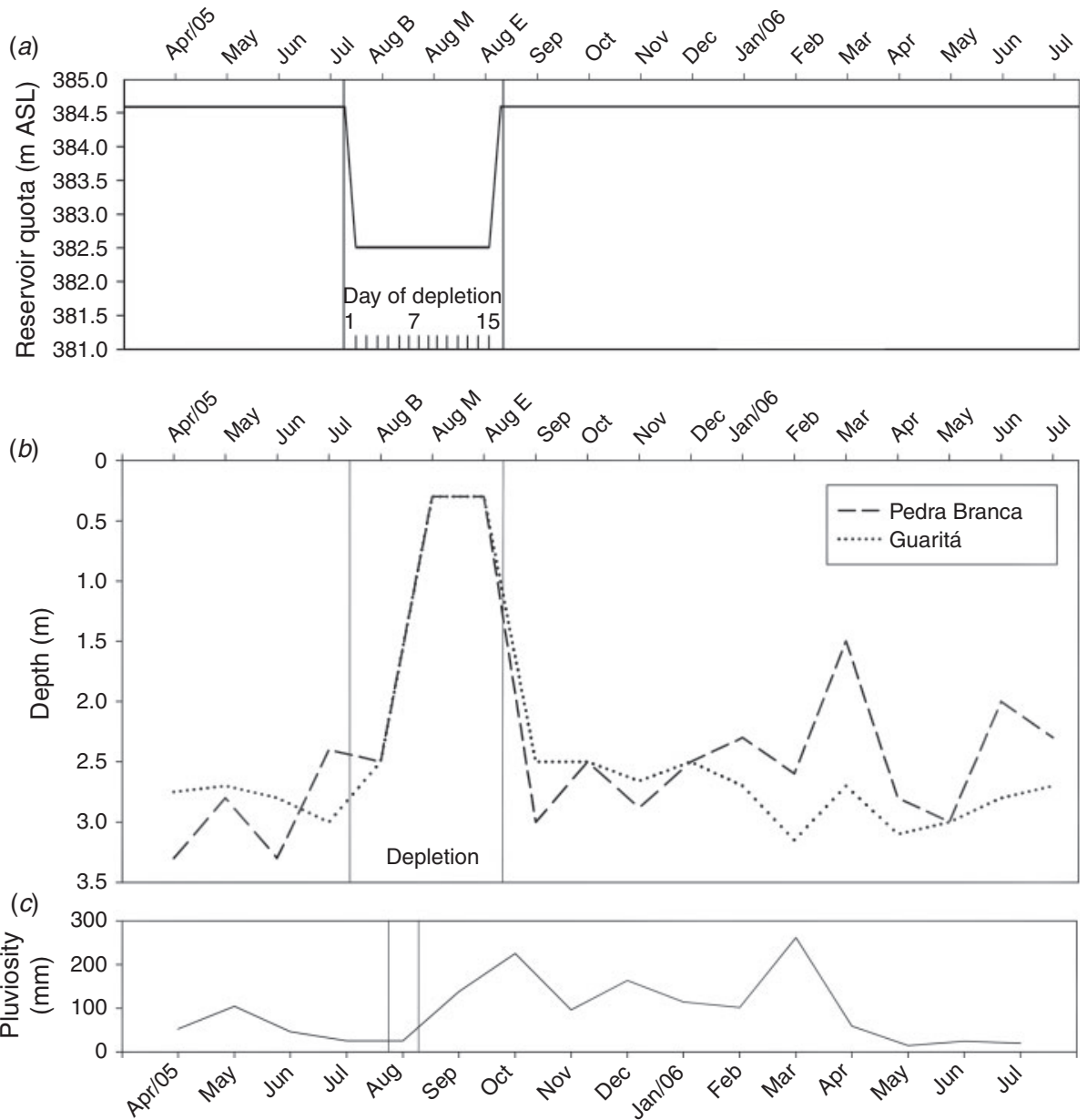

Fig. 2. Reservoir quota $(a)$, depth variation $(b)$ in lakes Pedra Branca and Guaritá and pluviosity $(c)$ during the study period. Depletion is highlighted between the vertical lines. B, M and E are the beginning, middle and end of drawdown respectively. (ASL, above sea level.)

\section{Data analysis}

To determine significant differences between the two lakes (higher and lower connected) and periods (before, during and after depletion) the Holm-Sidak All Pairwise Multiple Comparison Procedure was performed after a two-way analysis of variance $(P=0.05)$.

Cluster analysis was performed in order to identify the differences and similarities with respect to Cladocera community (Bray-Curtis distance, PC-ORD 5.31: McCune and Mefford 2006).

Using the environmental data and the cladoceran community data, a Canonical Correspondence Analysis (CCA) (PC-ORD 5.31: McCune and Mefford 2006) was performed to determine the overall lakes' responses during the study period.

\section{Results}

\section{Environmental variation}

The depth of the two lakes varied similarly, showing an amplitude of $\sim 3 \mathrm{~m}$ between the predepletion and depletion periods (Fig. 2b). Only Lake Pedra Branca was completely disconnected from the reservoir during the operational drawdown. Two precipitation peaks occurred during the study period, in October 2005 and March 2006 (Fig. 2c), following the typical seasonal pattern for the region, with a rainy warmer period (spring and summer) and a dry colder period (autumn and winter).

Both lakes were totally transparent throughout the study and most limnological variables varied similarly. Only DO was found to be significantly different, during the depletion, when the two lakes were compared $(t=3.226, P=0.003)$.

Pedra Branca had lower DO levels than Guaritá. At the end of the operational drawdown DO fell from $\sim 7$ to $3.5 \mathrm{mg} \mathrm{L}^{-1}$ in Pedra Branca (Fig. 3a). The pH also decreased in Pedra Branca during the depletion period and a sharp decrease to 5 units occurred in both lakes after depletion (October 2006) (Fig. 3b).

SM increased immediately after depletion (September 2006) in both lakes, being more pronounced in Lake Pedra Branca $\left(\sim 11 \mathrm{mg} \mathrm{L}^{-1}\right)$ than in Guaritá $\left(\sim 5 \mathrm{mg} \mathrm{L}^{-1}\right)$ (Fig. $\left.3 d\right)$.

Temperature, conductivity (especially in Pedra Branca) and chlorophyll peaked during the depletion period (Fig. $3 c, e$ and $f$ respectively). 

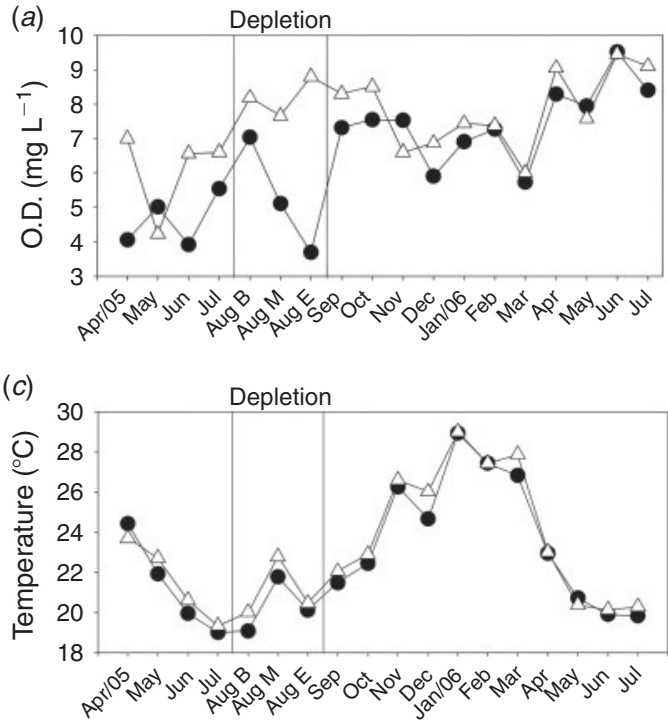

(e)

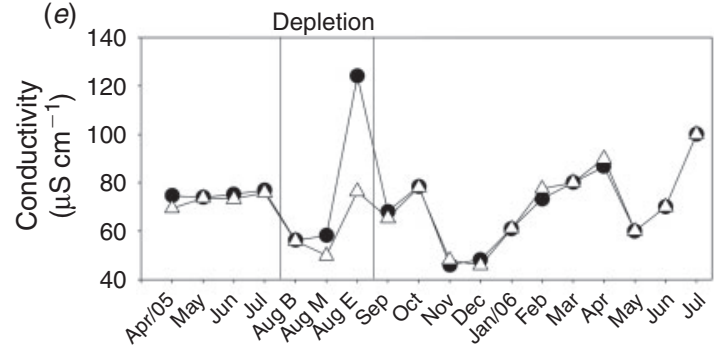

(g)
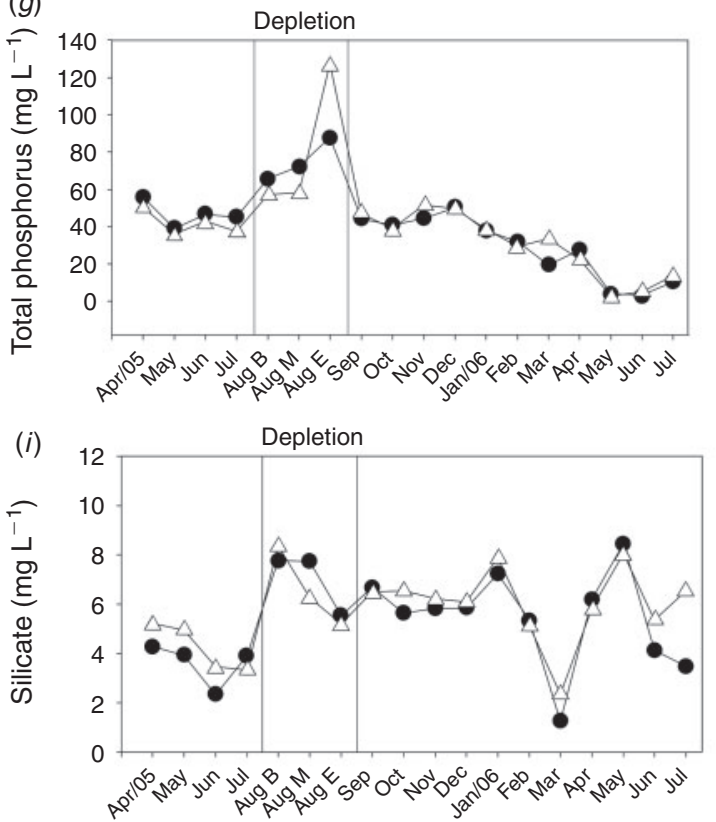

(b)

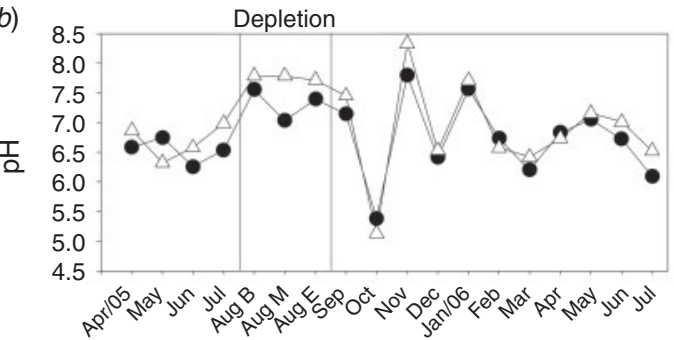

(d)
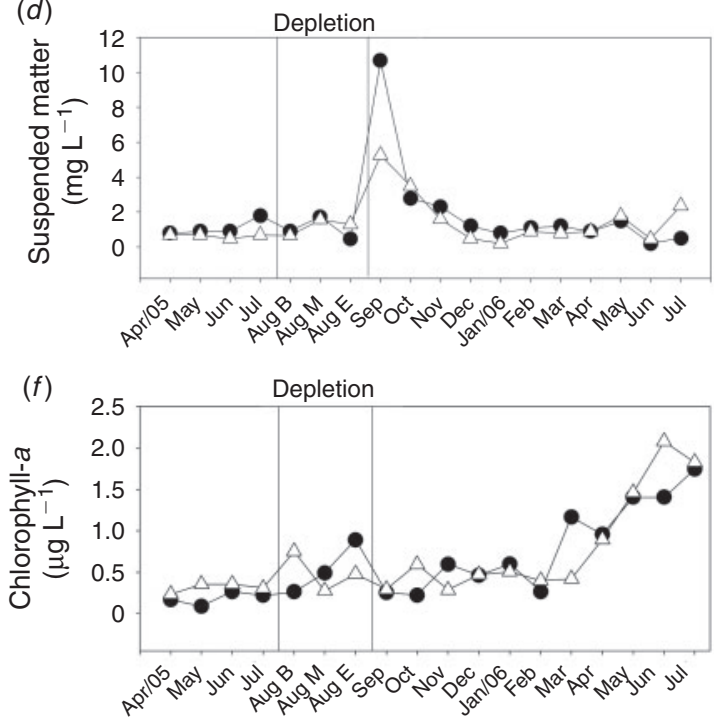

(h)

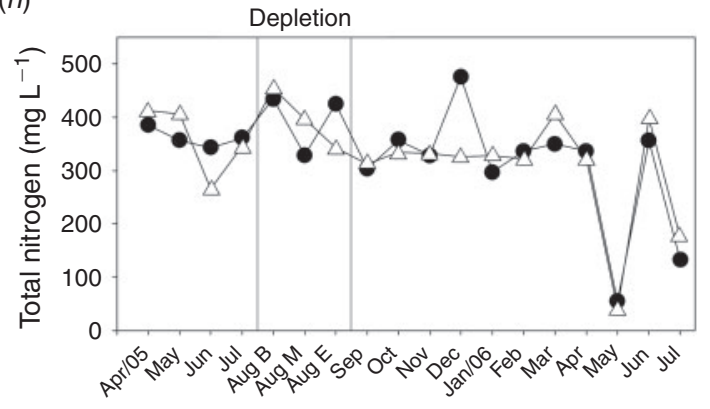

(j)

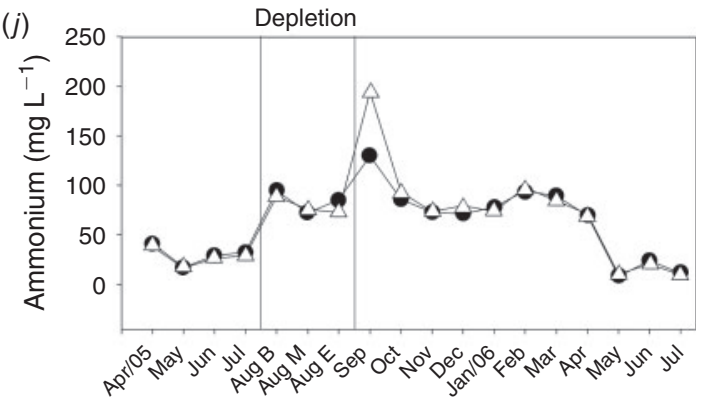

$$
\begin{aligned}
& \bullet \text { Pedra Branca } \\
& \triangle \_ \text {Guaritá }
\end{aligned}
$$

Fig. 3. Variation in the limnological variables $(a-j)$ measured in Lakes Pedra Branca and Guaritá during the study period. Depletion is highlighted between the vertical lines. B, $\mathrm{M}$ and $\mathrm{E}$ are the beginning, middle and end of drawdown respectively. 


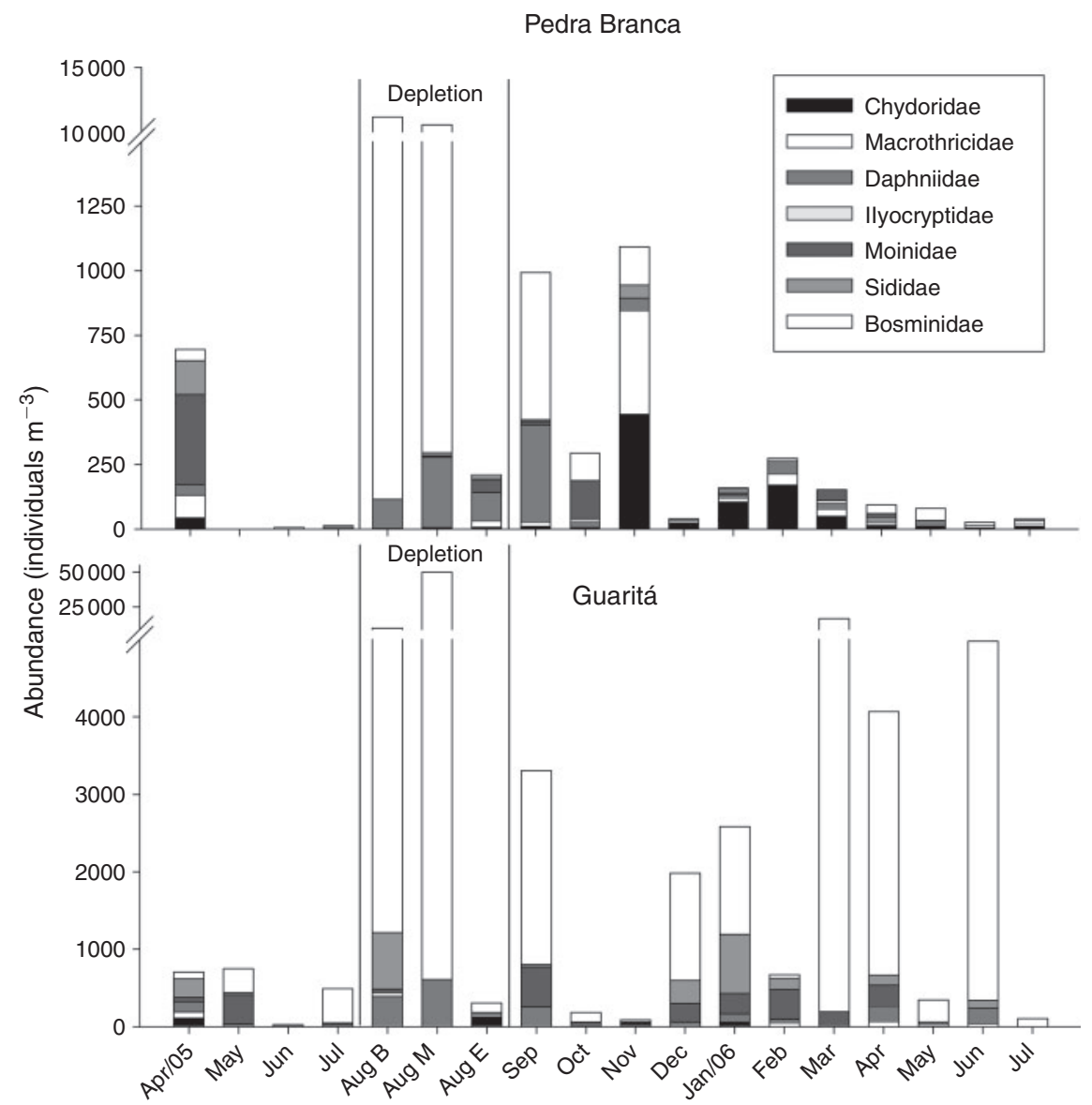

Fig. 4. Total abundance of the cladoceran families identified during the study period in Lakes Pedra Branca and Guaritá. Note the different scales on the $y$-axis. Depletion is highlighted between the vertical lines. $\mathrm{B}, \mathrm{M}$ and $\mathrm{E}$ are the beginning, middle and end of drawdown respectively.

The nutrient analysis performed during the drawdown showed high phosphorus release at the end of the depletion period (Fig. $3 g$ ). The ammonium concentration also increased, but not until the following month (Fig. 3j). Nitrogen (Fig. 3h) varied erratically, and silicate (Fig. 3i) was more highly concentrated after the depletion.

\section{Cladocera}

Forty-five cladoceran species were identified in this study (see list in the Accessory Publication), from the families Chydoridae (23 taxa), Daphniidae (7), Sididae (6), Moinidae (3), Bosminidae (3), Macrothricidae (2) and Ilyocryptidae (1) (Table S1).

After an initial increase in the number of organisms, mainly of Bosminidae, a noticeable decrease occurred at the end of the depletion period in both lakes (Fig. 4). In terms of mean values, the total abundance in Pedra Branca (1523 individuals $\mathrm{m}^{-3}$ ) was lower than in Guaritá (5390 individuals $\mathrm{m}^{-3}$ ).

During the procedure, higher heterogeneity occurred at the end of the depletion period, at which point the Daphniidae and Chydoridae dominated in Pedra Branca and the Chydoridae in Guaritá (Fig. 5).

An increase in mean richness and diversity was observed for both lakes after the depletion (Table 1), particularly in Pedra
Branca. The lowest mean diversity values were observed during the depletion.

Two main groups were observed for Pedra Branca in the cluster analysis (Fig. 6a). The first group, in the upper branch, represents months when abundance and diversity were intermediate, with the presence of both littoral and limnetic species. The second larger group represents months when abundance was generally lower, diversity was higher, and littoral species dominated rather than limnetic filter feeders. Samples from the beginning and middle of the depletion grouped as outliers: they had a high abundance of Bosmina freyi De Melo \& Hebert, 1994 (10894 and 14841 individuals $\mathrm{m}^{-3}$ respectively), which was not found in other samples. For the Lake Guaritá cluster (Fig. 6b) an upper branch group comprised the samples with low abundance of cladocerans. The internal subdivision of this group is based on the dominant species (Bosminopsis deitersi Richard, 1895, for the upper subgroup and Bosmina freyi for the lower subgroup). The second group found for Lake Guaritá comprises the samples with high abundances. Samples from the middle of the depletion were grouped as outliers because they had the highest abundance of bosminids found in the study (49 150 individuals $\mathrm{m}^{-3}$ ) whereas the month of June appeared as an outlier due to the presence of only two species (Ceriodaphnia 

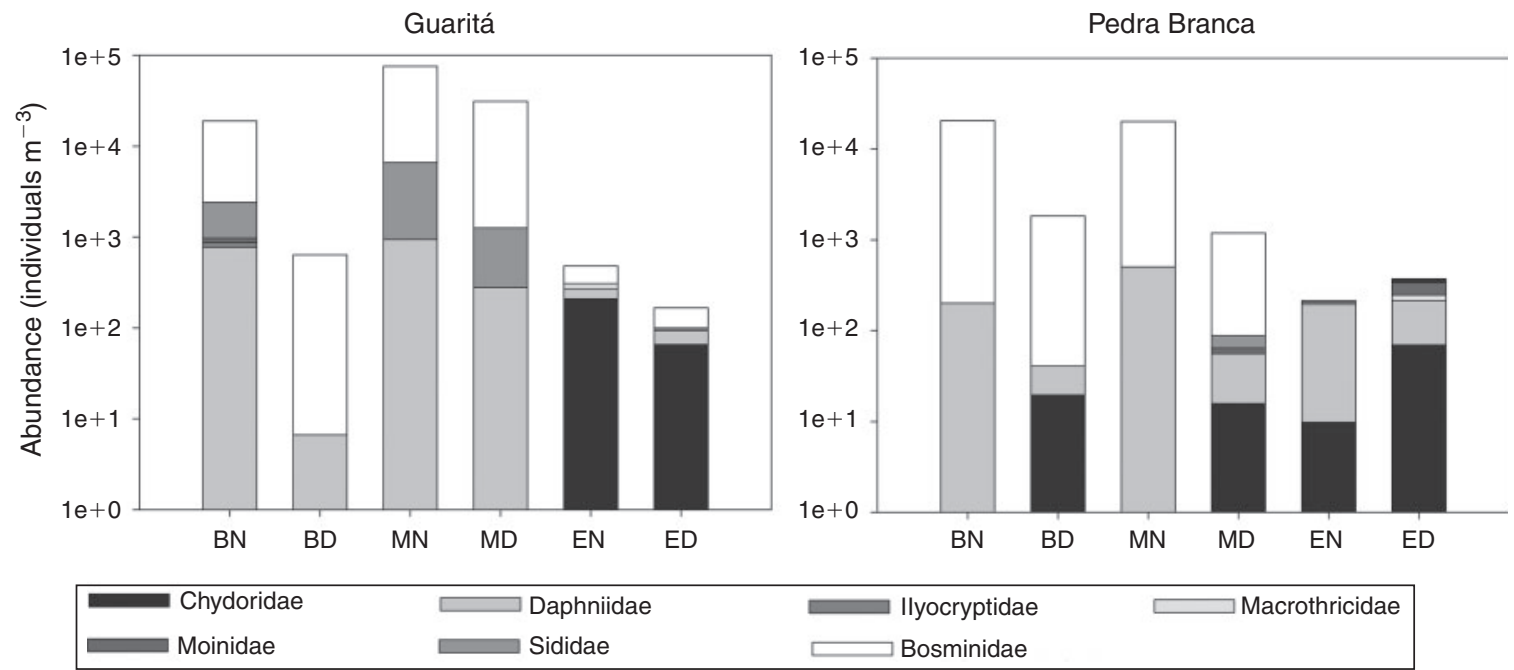

Fig. 5. Abundance of the cladoceran families identified during the depletion period in Lakes Pedra Branca and Guaritá. B, M and E are the beginning, middle and end of drawdown respectively; D, day; N, night.

Table 1. Mean richness and diversity (Shannon-Wiener) of cladocerans observed during the study period in Lakes Pedra Branca and Guaritá

\begin{tabular}{lrccc}
\hline & \multicolumn{2}{c}{ Guaritá } & \multicolumn{2}{c}{ Pedra Branca } \\
& Richness & Diversity & Richness & Diversity \\
\hline Entire study period & 11.5 & 1.14 & 11.2 & 1.28 \\
Before depletion (winter) & 7.3 & 1.06 & 7.0 & 0.77 \\
During depletion & 8.3 & 0.90 & 8.0 & 0.68 \\
After depletion (summer) & 16.0 & 1.48 & 14.3 & 1.61 \\
After depletion (winter) & 12.8 & 0.82 & 15.0 & 1.64 \\
After depletion (total) & 14.5 & 1.24 & 14.3 & 1.62 \\
\hline
\end{tabular}

silvestrii Daday, 1902, 7 individuals $\mathrm{m}^{-3}$ and Moina minuta Hansen, 1899, 20 individuals $\mathrm{m}^{-3}$ ).

No clear pattern of differentiation between the lakes was observed in the CCA analysis (Fig. 7), except for the differential positioning of the end of the depletion (G7 and P7), mainly related to the peak of conductivity observed in Pedra Branca. The influence of the dominant bosminid species can be observed to create a horizontal gradient, with the more diversified samples being disposed between these extremes.

\section{Discussion}

\section{Effects of depletion on the limnological variables}

Despite the similar patterns of variation, greater variation in the limnological characteristics was observed in Lake Pedra Branca, where the water quality was lower. The morphology of this lateral lake, which remains isolated from the main axis of the reservoir during the drawdown, and its greater abundance of macrophytes are the most likely explanations of why this lake is more strongly affected by operational depletion.

In Lake Guaritá, the internal effects of the physical and chemical particularities and effects of the activities of the biota could be minimised because of the higher water exchange with the main channel of the reservoir, whereas the compartmentalisation and isolation of Pedra Branca prevented such homogenisation. In a regional context, the degree of connectivity of lateral lakes to the main water body has been considered a key factor explaining the limnological variability of the whole system (Granado and Henry 2012; Ferrareze et al. 2014).

The massive occurrence of macrophytes and associated metabolic processes (photosynthesis, respiration, excretion, decomposition) directly influence the water chemistry (Carpenter and Lodge 1986). The higher concentration of plants in Pedra Branca leads to more extreme responses of the limnological variables when compared with Guaritá.

Different variables took different times to respond to the effects of the drawdown. The $\mathrm{pH}$ and $\mathrm{DO}$ decreased at the beginning of the process, whereas conductivity and SM were affected only at the end of the drawdown and 1 month after depletion respectively. This differential time-lag is related to the sequence of events. In the beginning and middle of the depletion period, the water level is diminished and most of the macrophyte beds in the littoral zone are exposed to the air. The changes in $\mathrm{pH}$ and DO are most likely caused by biological activity of the communities trapped under the remaining underwater beds, including intense respiration and decomposition of labile organic matter. After restoration of the quota, the dead biomass from the macrophytes becomes rehydrated, leading to the dissolution of the cellular contents of the dead portion of the plants and an increase in conductivity due to the large amount of released dissolved ions. The simultaneous increase in phosphorus confirms this assumption. As the decomposition of long-chain molecules from the cell walls of the macrophytes requires a longer period than the dissolution of cell contents, an increase in the amount of suspended matter (essentially from dead macrophytes) was observed only in the following month. Similar responses have been observed by Carvalho et al. (2005). 

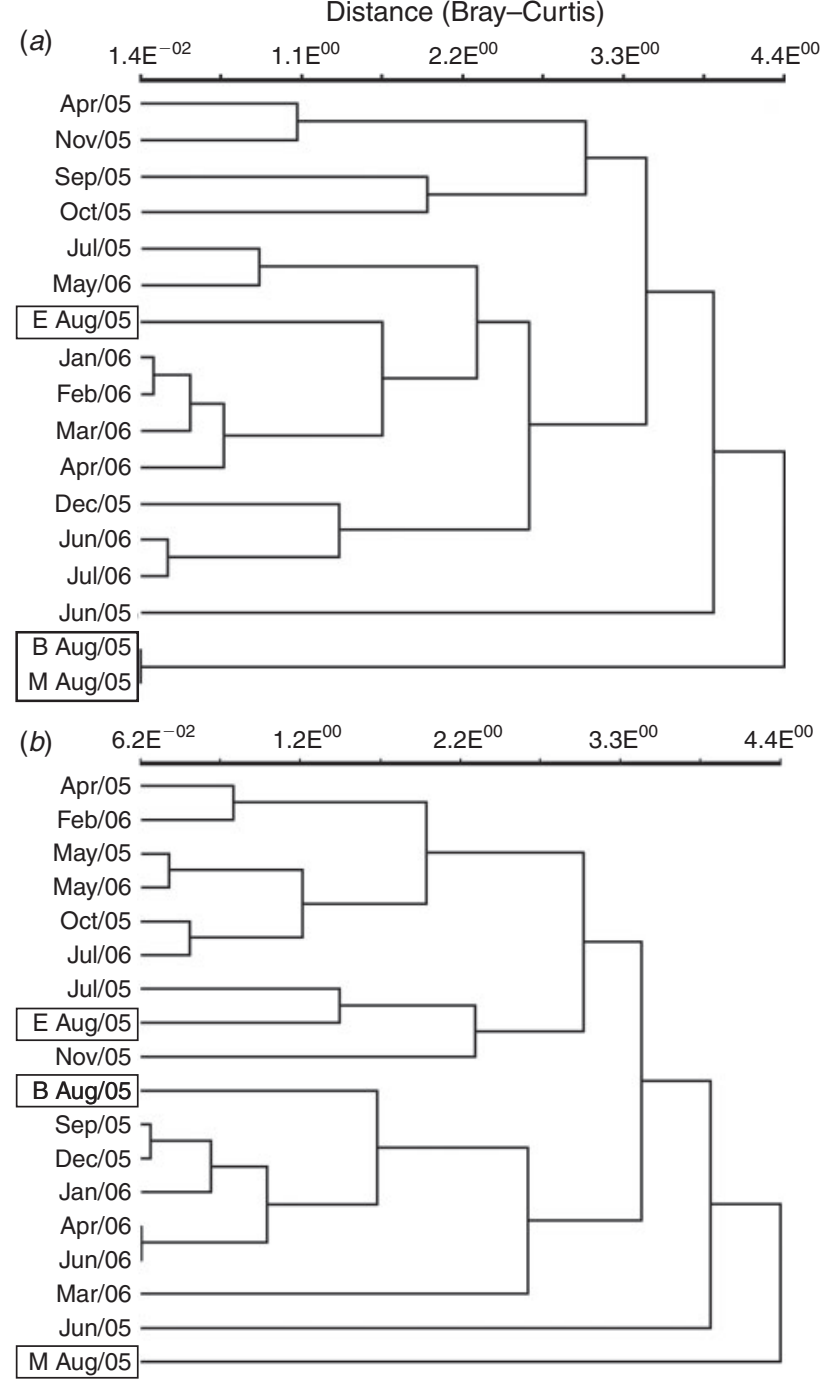

Fig. 6. Cluster dendrogram based on the cladoceran community using the Bray-Curtis index for Lakes Pedra Branca $(a)$ and Guaritá $(b)$ during the study period. B, M and E are the beginning, middle and end of drawdown respectively.

\section{Effects of depletion on the cladoceran community}

The cladoceran community found in this study increases the number of known species of this reservoir from 39 (PerbicheNeves and Nogueira 2010) to 45. This increase probably occurred because of the extensive sampling effort carried out in our study (16 consecutive months).

Regarding the recorded variation of the cladoceran assemblages, the two lakes showed contrasting scenarios. Limnetic filter feeders dominated Lake Guaritá during most of the study period, and also in the main channel of the reservoir (PerbicheNeves and Nogueira 2010). In Lake Pedra Branca littoral species were dominant in the wet season, whereas limnetic filter feeders were abundant during the dry periods and especially during the depletion. These differences confirmed the assumption that the biota of Lake Pedra Branca differs from that of Lake Guaritá despite their physical proximity.

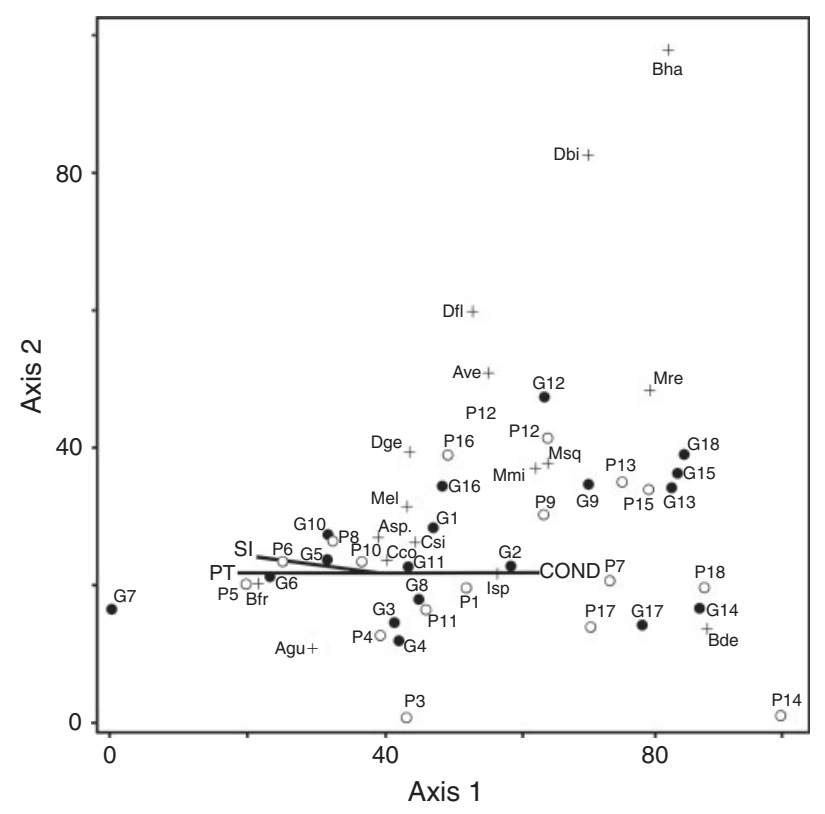

Fig. 7. CCA based on the correlations between cladoceran variation and environmental variation during the study period. Abbreviations: $G$, Lake Guaritá; P, Lake Pedra Branca. The numbers indicate the sampling sequence (1, April 2005; 2, May 2005, etc.; 5, 6 and 7 represent the beginning, middle and end of the drawdown in August 2005). For species codes, see the Supplementary material.

Factors intrinsic to the lake can be of major importance in the structuring of communities (Hobæk et al. 2002; Eitam et al. 2004) and appear to be more effective in Pedra Branca than in Guaritá. The sheltered conditions in Pedra Branca promote the development of extensive macrophyte cover that can drive off limnetic plankton because of predation risk (Meerhoff et al. 2006). The macrophytes also provide higher spatial complexity, which may help to maintain a more diversified community (McAbendroth et al. 2005; Thomaz et al. 2008; Thomaz and Cunha 2010; Ferreiro et al. 2011; Debastiani-Júnior et al., in press).

The characteristics of both lakes tended towards a more similar state in the dry periods during the study, with higher abundance of filter feeders. Frutos and Carnevali (2008) observed a higher abundance of zooplankton in an artificial lake dominated by cyanobacteria than in a similar-sized lake dominated by macrophytes, and Frutos et al. (2009) observed peaks of zooplankton in eutrophication events in two lakes in the Corrientes region, Argentina. Higher densities of zooplankton have also been observed in floodplain lakes of the Pantanal during the low-water phase (Fantin-Cruz et al. 2011). This type of response resembles that seen in the present study, with zooplankton experiencing intensive growth and concentration during the period of macrophyte suppression when eutrophication was high and water level low.

Nevertheless, the conditions during depletion differ from those of the other dry months, showing extreme dominance by bosminids in the lakes, a strong indicator of the potential interference of the operational management measure in the system. The Bosminidae are adapted for food selection in 
environments with high content of suspended matter (Acharya et al. 2005), which can result from the decomposition of macrophytes in the lakes and from algae blooms, being generally recognised as a bio-indicator of decreased water quality conditions. In reservoirs the community is expected to be dominated by Daphniidae, which has been observed for the main channel of Salto Grande (Perbiche-Neves and Nogueira 2010). Therefore, the development, maintenance and high concentration of Bosminidae during depletion, representing a poorer condition of the aquatic fauna, corroborates the environmental impoverishment previously observed by limnological analysis. Although bosminids increased considerably in both lakes, the conditions in Lake Pedra Branca deviated more from the natural state.

An increase in richness and diversity was observed in the end and after the depletion, showing that the cladoceran community is resilient. Because of the possibility of fast recolonisation, both by hatching from local egg banks (Panarelli et al. 2008) or by direct or indirect exchange with other water bodies (Allen 2007) the cladoceran community can quickly recover from water level fluctuations. With the combination of both above-mentioned strategies it is unlikely that the depletion will directly suppress the richness and diversity of cladocerans in Salto Grande.

Although water level fluctuation apparently directly influences only the fauna that cannot withstand dehydration, which is not the case for the Cladocera, indirect effects (i.e. changes in habitat structure) are more pronounced (Leira and Cantonati 2008). Cases of change in the steady-state of reservoirs due to management are reported in the literature (Daldorph 1999). For Salto Grande reservoir, the studied lateral lakes can be assumed to be in different equilibrium states, exhibiting contrasting biological communities, although their limnological components show some degree of similarity. We suggest that these differences are mostly caused by the higher density of macrophytes in Pedra Branca.

As proposed by Scheffer and Carpenter (2003), the magnitude of changes required to cause a change in the steady-state is considerably smaller than that required to return to the initial conditions. If the continuous management of Salto Grande Reservoir achieves the threshold for macrophyte suppression the original conditions in Pedra Branca will hardly be recovered. As a consequence, the high diversity and richness of Cladocera associated with the macrophytes will not be able to re-establish after disturbance (seasonal or man-made) because of the lack of appropriate habitat for the benthic fauna and the relief of predation pressure on filter feeders.

\section{Conclusions}

Our results partially refute both hypotheses of this work. Stronger effects on the limnological variables measured were observed in Pedra Branca, as expected, but similar patterns were detected in Guaritá, despite the smaller range of variation. With respect to the Cladocera, although the resistance to river channel intrusion was stronger in Pedra Branca than in Guaritá, it was not sufficient to prevent the invasion of opportunistic taxa during the drawdown. The conditions in Guaritá during the management procedure also did not differ greatly from the previous conditions. In both lakes, abundance increased during depletion, indicating that even with the constant connectivity of Guaritá, concentration effects on fauna could be observed, rather than the expected washout.

The effects of the depletion event on Lake Pedra Branca could be observed not only during the operational procedure but also afterwards. During the procedure great disruption from the previous conditions were observed and after the procedure a recolonisation dynamic took place. The observed variation of the environmental conditions and cladoceran community of Lake Pedra Branca indicates that restabilisation of this lake after drawdown requires a longer period compared with Guaritá. The continuous use of this strategy for reducing the macrophyte cover may lead to a change in the steady-state equilibrium of this lake, including a local loss of diversity due to habitat destruction that might be difficult to reverse.

\section{Acknowledgements}

The authors acknowledge the Fundação de Amparo à Pesquisa do Estado de São Paulo (FAPESP process 2007/03015-8) for the scholarship received by the first author, and Duke Energy for financial support. We also thank Dr Silvia M. C. Casanova for her participation during the development of the project. Finally, the authors thank the anonymous reviewers for insightful suggestions to improve this manuscript.

\section{References}

Acharya, K., Jack, J. D., and Bukaveckas, P. A. (2005). Dietary effects on life history traits of riverine Bosmina. Freshwater Biology 50, 965-975. doi:10.1111/J.1365-2427.2005.01379.X

Allen, M. R. (2007). Measuring and modeling dispersal of adult zooplakton. Oecologia 153, 135-143. doi:10.1007/S00442-007-0704-4

Carpenter, S. R., and Lodge, D. M. (1986). Effects of submersed macrophytes on ecosystem processes. Aquatic Botany 26, 341-370. doi:10.1016/0304-3770(86)90031-8

Carvalho, P., Thomaz, S. M., and Bini, L. M. (2005). Effects of temperature on decomposition of potential nuisance species: the submerged aquatic macrophyte Egeria najas Planchon (Hydrocharitaceae). Brazilian Journal of Biology 65, 51-60. doi:10.1590/S1519-69842005000100008

Daldorph, P. W. G. (1999). A reservoir in management-induced transition between ecological states. Hydrobiologia 395/396, 325-333. doi:10.1023/A:1017038728048

Debastiani-Júnior, J. R., Elmoor-Loureiro, L. M. A., and Nogueira, M. G. Influence of habitat structure on Cladocera (Crustacea Branchiopoda) species composition. Brazilian Journal of Biology, in press.

Eitam, A., Blaunstein, L., Van Damme, K., Dumont, H. J., and Martens, K. (2004). Crustacean species richness in temporary pools: relationships with habitat traits. Hydrobiologia 525, 125-130. doi:10.1023/B:HYDR. 0000038859.51416.7D

Elmoor-Loureiro, L. M. A. (1997). 'Manual de Identificação de Cladóceros Límnicos do Brasil', 1st edn. (Universia: Brasília.)

Fantin-Cruz, I., Loverde-Oliveira, S. M., Bonecker, C. C., Girad, P., and Motta-Marque, D. (2011). Relationship between the structure of zooplankton community and the water level in a floodplain lake from the Pantanal, Mato Grosso State, Brazil. Acta Scientiarum Biological Sciences 33, 271-279. doi:10.1023/B:HYDR.0000038859.51416.7D

Ferrareze, M., and Nogueira, M. G. (2011). Importance of lateral lagoons for the ichthyofauna in a large tropical reservoir. Brazilian Journal of Biology 71, 807-820. doi:10.1590/S1519-69842011000500002

Ferrareze, M., Nogueira, M. G., and Sartori, L. (2014). Limnology of a lateral lagoon system connected to a Neotropical reservoir (Rosana Reservoir, São Paulo/Patraná, Brazil). Acta Scientiarum Biological Sciences 36, 197-207. doi:10.4025/ACTASCIBIOLSCI.V36I2.21491

Ferreiro, N., Feijoó, C., Giorgi, A., and Leggieri, L. (2011). Effects of macrophyte heterogeneity and food availability on structural parameters 
of the macroinvertebrate community in a Pampean stream. Hydrobiologia 664, 199-211. doi:10.1007/S10750-010-0599-7

Forró, A., Korovchinsky, N. M., Kotov, A. A., and Petrusek, A. (2008). Global diversity of cladocerans (Cladocera; Crustacea) in freshwater. Hydrobiologia 595, 177-184. doi:10.1007/S10750-007-9013-5

Frutos, S. M., and Carnevali, R. (2008). Zoo-heleoplankton structure in three artificial ponds of north-eastern Argentina. Revista de Biologia Tropical 56, 1135-1147

Frutos, S. M., Poi de Neiff, A. S. G., and Neiff, J. J. (2009). Zooplankton abundance and species diversity in two lakes with different trophic states (Corrientes, Argentina). Acta Limnologica Brasiliensia 21, 367-375.

Golterman, K. L., Clymo, R. S., and Ohmstad, M. A. M. (1978). 'Methods for Physical and Chemical Analysis of Freshwaters', 2nd edn. (Scientific Publications: Oxford, UK.)

Granado, D. C., and Henry, R. (2012). The influence of the hydrologic pulse on the water physical and chemical variables of lateral lakes with different connection levels to Paranapanema River in the mouth zone at Jurumirim Reservoir (São Paulo, Brazil). Acta Limnologica Brasiliensia 20, 265-275.

Hobæk, A., Manca, M., and Andersen, T. (2002). Factors influencing species richness in lacustrine zooplankton. Acta Oecologica 23, 155-163. doi:10.1016/S1146-609X(02)01147-5

Jeppesen, E., Jensen, J. P., Søndergaard, M., Lauridsen, T., Pedersen, L. J., and Jensen, L. (1997). Top-down control in freshwater lakes: the role of nutrient state, submerged macrophytes and water depth. Hydrobiologia 342/343, 151-164. doi:10.1023/A:1017046130329

José de Paggi, S. B., and Paggi, J. C. (2008). Hydrological connectivity as a shaping force in the zooplankton community of two lakes in the Paraná River floodplain. International Review of Hydrobiology 93, 659-678. doi:10.1002/IROH.200711027

Junk, W. J., Bayley, P. B., and Sparks, R. E. (1989). The flood pulse concept in river-floodplain systems. In 'Proceedings of the International Large River Symposium (LARS)', 14-21 September 1986, Honey Harbour, ON, Canada. pp. 110-127. (Canadian Special Publication of Fisheries and Aquatic Sciences:, Ottawa, ON, Canada.)

Korovchinsky, N. M. (1992). 'Sididae \& Holopedidae. Guides to the Identification of Microinvertebrates of the Continental Waters of the World', vol. 3. (Ed. H. J. Dumont.) (SPB Academic Publishing: Hague, Netherlands.)

Leira, M., and Cantonati, M. (2008). Effects of water-level fluctuations on lakes: an annotated bibliography. Hydrobiologia 613, 171-184. doi:10.1007/S10750-008-9465-2

Mackereth, F. I. H., Heron, J., and Talling, J. F. (1978). 'Water Analysis: Some Revised Methods for Limnologists.' (Freshwater Biological Association: London.)

McAbendroth, L., Ramsay, P. M., Foggo, A., Rundle, S. D., and Bilton, D. T. (2005). Does macrophyte fractal complexity drive invertebrate diversity, biomass and body size distributions? Oikos 111, 279-290. doi:10.1111/ J.0030-1299.2005.13804.X

McCune, B., and Mefford, M. J. (2006). PC-ORD. Multivariate Analysis of Ecological Data. Version 5.31 MjM Software. (Gleneden Beach, Lincoln County, OR, USA.)

Meerhoff, M., Fosalba, C., Bruzzone, C., Mazzeo, N., Noordoven, W., and Jeppesen, E. (2006). An experimental study of habitat choice by Daphnia: plants signal danger more than refuge in subtropical lakes. Freshwater Biology 51, 1320-1330. doi:10.1111/J.1365-2427.2006.01574.X

Nogueira, M. G., Perbiche-Neves, G., and Naliato, D. A. O. (2012) Limnology of two contrasting hydroelectric reservoirs (storage and run-of-river) in southeast Brazil. In 'Hydropower - Practice and Application'. (Ed. H. S. Borougeni.) pp. 167-184. (INTECH: Rijeka, Croatia.)

Orlova-Bienkowskaja, M. J. (1998). A revision of the cladoceran genus Simocephalus (Crustacea, Daphniidae). Bulletin of the Natural History Museum, London 64, 1-62.
Panarelli, E. A., Casanova, S. M. C., and Henry, R. (2008). The role of resting eggs in the recovery of zooplankton community in a marginal lake of the Paranapanema River (São Paulo, Brazil), after a long drought period. Acta Limnologica Brasiliensia 20, 73-88.

Pelicice, F. M., Agostinho, A. A., and Thomaz, S. M. (2005). Fish assemblages associated with Egeria in a tropical reservoir: investigating the effects of plant biomass and diel period. Acta Oecologica 27, 9-16. doi:10.1016/J.ACTAO.2004.08.004

Perbiche-Neves, G., and Nogueira, M. G. (2010). Multi-dimensional effects on Cladoceran (Crustacea, Anomopoda) assemblages in two cascade reservoirs in southeast Brazil. Lakes and Reservoirs: Research and Management 15, 139-152. doi:10.1111/J.1440-1770.2010.00429.X

Poi de Neiff, A. (2003). Macroinvertebrates living on Eichornia azurea Kunth in the Paraguay River. Acta Limnologica Brasiliensia 15, 55-63.

Roche, K. F., and Rocha, O. (2005). 'Ecologia Trófica de Peixes com Ênfase na Planctivoria em Ambientes Lênticos de Água Doce no Brasil.' (Rima: São Carlos.)

Sarma, S. S. S., Nandini, S., and Gulati, R. D. (2005). Life history strategies of cladocerans: comparisons of tropical and temperate taxa. Hydrobiologia 542, 315-333. doi:10.1007/S10750-004-3247-2

Scheffer, M., and Carpenter, S. R. (2003). Catastrophic regime shifts in ecosystems: linking theory to observation. Trends in Ecology \& Evolution 18, 648-656. doi:10.1016/J.TREE.2003.09.002

Scheffer, M., and van Geest, G. J. (2006). Small habitat size and isolation can promote species richness: second-order effects on biodiversity in shallow lakes and ponds. Oikos 112, 227-231. doi:10.1111/J.0030-1299. 2006.14145.X

Shimabukuro, E. M., and Henry, R. (2011). Controlling factors of benthic macroinvertebrates distribution in a small tropical pond, lateral to the Paranapanema River (São Paulo, Brazil). Acta Limnologica Brasiliensia 23, 154-163. doi:10.1590/S2179-975X2011000200006

Smirnov, N. N. (1996). Cladocera: the Chydorinae and Sayciinae (Chydoridae) of the World. In 'Guides to the Identification of the Microinvertebrates of the Continental Waters of the World'. (Ed. H. J. Dumont.) (SPB Academic Publishing: Amsterdam.)

Strickland, J. D., and Parsons, T. R. (1960). A manual of sea water analysis. Bulletin - Fisheries Research Board of Canada 125, 1-185.

Thomaz, S. M., and Cunha, E. R. (2010). The role of macrophytes in habitat structuring in aquatic ecosystems: methods of measurement, causes and consequences on animal assemblages' composition and biodiversity. Acta Limnologica Brasiliensia 22, 218-236. doi:10.4322/ACTALB. 02202011

Thomaz, S. M., Pagioro, T. A., Bini, L. M., and Murphy, K. J. (2006). Effect of reservoir drawdown on biomass of three species of aquatic macrophytes in a large sub-tropical reservoir (Itaipu, Brazil). Hydrobiologia 570, 53-59. doi:10.1007/S10750-006-0161-9

Thomaz, S. M., Dibble, E. D., Evangelista, L. R., Higuti, J., and Bini, L. M. (2008). Influence of aquatic macrophyte habitat complexity on invertebrate abundance and richness in tropical lagoons. Freshwater Biology $\mathbf{5 3}, 358-367$.

Valderrama, J. G. (1981). The simultaneous analysis of total nitrogen and phosphorus in natural waters. Marine Chemistry 10, 109-122. doi:10.1016/0304-4203(81)90027-X

Ward, J. V. (1989). The four-dimensional nature of lotic ecosystems Journal of the North American Benthological Society 8, 2-8. doi: $10.2307 / 1467397$

Ward, J. V., Tockner, K., and Schiemer, F. (1999). Biodiversity of floodplain river ecosystems: ecotones and connectivity. Regulated Rivers: Research and Management 15, 125-139. doi:10.1002/(SICI)10991646(199901/06)15:1/3<125::AID-RRR523>3.0.CO;2-E

Zalocar de Domitrovic, Y.Z. (2002). Structure and variation of the Paraguay River phytoplankton in two periods of its hydrological cycle. Hydrobiologia 472, 177-196. doi:10.1023/A:1016304803431 